ARTICLE

\title{
Assessing the Effectiveness of Adhoc-Network and Electronic Govern- ment in Abuja, Nigeria
}

\author{
Ibrahim Goni $^{1^{*}} \quad$ Abdulrahman Saidu $^{2} \quad$ Umar Maigari T. $^{3} \quad$ Murtala Mohammad $^{1}$ \\ 1. Department of Computer Science, Faculty Science, Adamawa State University Mubi, Adamawa, Nigeria \\ 2. Department of Computer Science, Faculty of Science, Federal Polytechnic Bali, Taraba, Nigeria \\ 3. Department of Computer Science, Faculty of Science, Federal College of Education Gombe, Gombe state, Nigeria
}

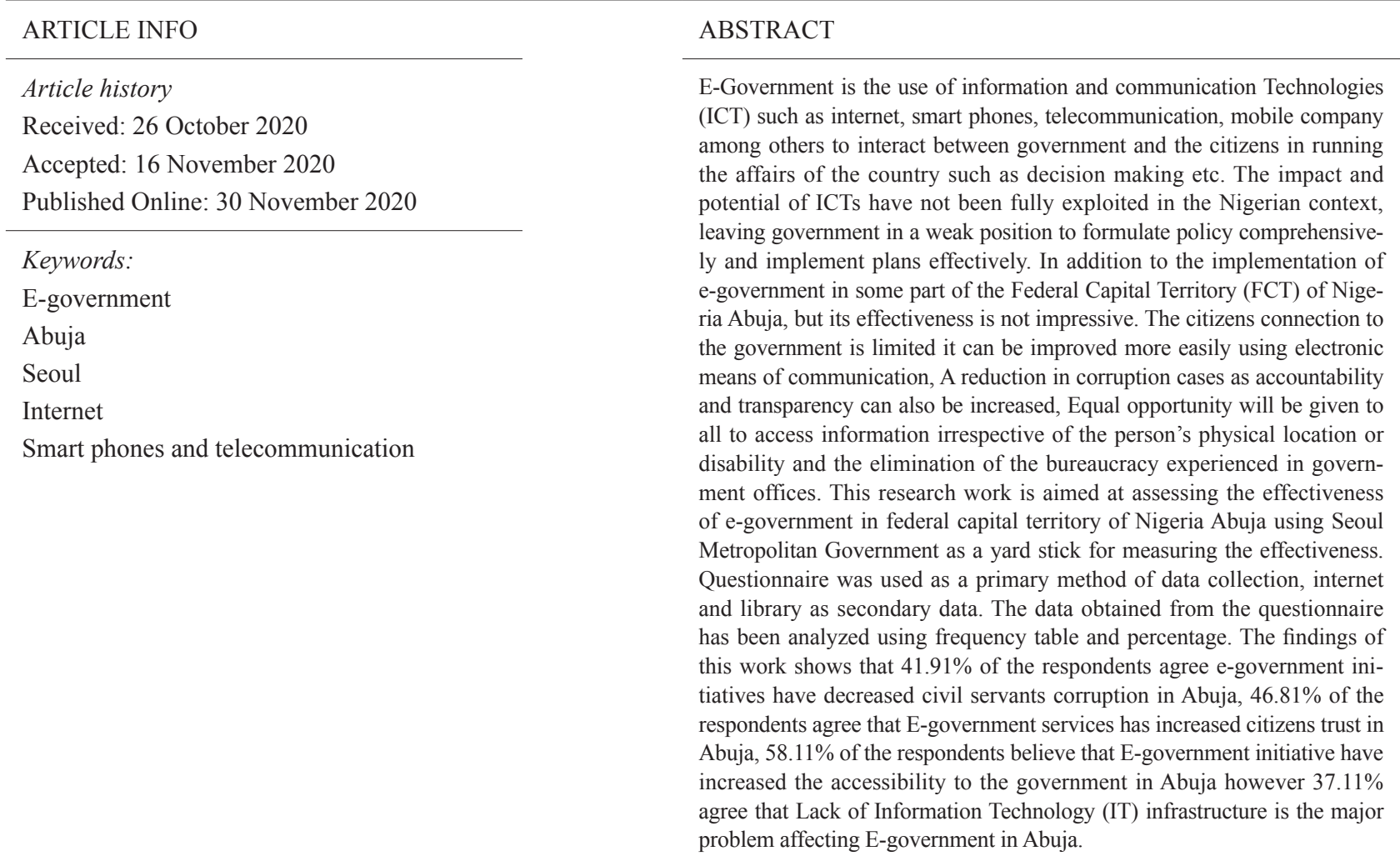

\section{Introduction}

tance is never a barrier. We are witnessing the simultaneous advancement in artificial intelligence, nanotechnology, Neuro-computing, robotics engineering, big data, data science, precious agriculture, block-chain, and other fast emerging technologies specifically artificial intelligence.

*Corresponding Author:

Ibrahim Goni,

Department of Computer Science, Faculty Science, Adamawa State University Mubi, Adamawa, Nigeria; Email: algonis1414@gmail.com 
These frontier technologies are techniques used in food systems, water and sanitation, energy, to education, health care and social services among others.

\subsection{Background to the Study}

Globally, there is growing body of knowledge for acceptability of e-government ${ }^{[12-18]}$. With the innovations in IT collaboration, sharing, contributions, participating in government and even transparency between governance and citizens has become a reality. E-Government has created an interactive session between her governance and citizens in terms of taking decisions and running the affairs of the country ranging from economy to policy, leadership to security ${ }^{[19]}$. However, ${ }^{[5]}$ described it as "The quest is multi-dimensional across leadership, policy, economic competitiveness, education, digital citizen's services, internal government operations, digital democracy, and enabling technologies for each dimension." She further believed that each dimension require leadership, strategy, cross-coordination and technical know-how all joint together with a technology strategy to take the vision to reality.

In addition to ${ }^{[1]}$ assert that "Nigeria is regarded as the giant of Africa" in the international system, in terms of population density not in technological growth but he further agree that Nigeria, is like every other nation in the global community is striving to achieve a standard where e-governance becomes the order of the day. Awareness on the importance of E-government has grown significantly in developing countries, along with the exponential growth of technology and ICT convergence. Moreover, E-governance has created a virtual government that changes the traditional relationship between government and her citizens ${ }^{[4]}$. However, ${ }^{[2]}$ believed that accessibility, security and privacy are three pillars of digital government. In the work of ${ }^{[9]}$ described privacy as an essential pillar of trusted interactions in commerce, health care digital communications, financial matters, education among other areas.

\subsection{Statement of the Problem}

The impact and potential of ICTs have not been fully exploited in the Nigerian context, leaving government in a weak position to formulate policy comprehensively and implement plans effectively. Despite the fact that skeletal E-government has been implemented for a while now in federal capital territory of Nigeria Abuja, but its effectiveness is not impressive. The citizen's connection to the government is limited. The rate of corruption cases is alarming every day. Lack of transparency and accountabil-

ity among civil servant is at increase day-by-day because there is no full implementation of e-government.

\section{Literature Review}

This section presents a thorough review of publications relating to electronic governance and it also provides a detail description of the area under study.

Electronic government is the application of information technology in deriving the processes of government, ${ }^{[6]}$ assert that "The central goal of e-governance is to establish a concrete relationship between government officials in the state and the citizenry, providing full access of information to the citizenry and even the entire world; giving an avenue to the citizens to participate in making government decisions, such as by requesting government service and filing required documents through website; in addition to create more transparency and accountability among government officials in-line with this believed ${ }^{[6]}$ also observed that E-government uses tools offered by information and communication technology in various aspect and processes of governance with the hope and hype of achieving efficiency, transparency, accountability and user friendliness in all the transactions that the citizens and businesses indulge with the government.

In the context of this research work E-government uses information and communication technology tools which are dependable and reliable to the various processes of government, citizen and businesses in a country. In the Nigerian context, the rapid growth of information technology in the $21^{\text {st }}$ century has forced Nigeria to embrace e-governance. The privatization of NITEL in 2001 is the key factor that contributed to this development going by Nigerian Communications Commission (NCC) 2014 statistics, Nigeria has over 130 Million Active Mobile Phone Subscribers, of which 63 million are connected to the internet most probably through their phones (http:// www.thenigerianvoice.com/). As indicated by ${ }^{[6]}$ "In response to this growing reality and to move along with the global drift the Federal Government of Nigeria (FGN) adopted a national policy on Information technologies and is prepared to integrate Agriculture, health, education etc." According to ${ }^{[1]}$ between 2011 and 2013, Nigerian government had adopted various online procedures such as mobile apps and mobile portals to directly support poverty eradication, gender equality, social inclusion and the promotion of economic development, environmental protection and disaster management.

Moreover, ${ }^{[1]}$ identified six benefit of e-government these are; (1) Cost reduction and efficiency gains (2) Quality of service delivery to businesses and customers (3) Transparency, anticorruption, accountability (4) Increase 
the capacity of government (5) Network and community creation (6) Improve the quality of decision making and (7) Promote use of ICT in other sectors of the society. In addition to ${ }^{[8]}$ assert that the traditional Government is confronted by new technologies in two different ways; e-policy and interactive e-government. E-policy entails the legal framework governing the use of IT (e.g. recognition of the digital signature), The second aspect is the interactive e-government that has to deal with defining its role as a market layer in the virtual environment, he further agree that e-government has two dimension; Endowing the economy with the necessary legal frame work and performing it work in an effective manner. With the exponential growth in information and communication technology today ${ }^{[7]}$ suggested that the common phrases are e-governance, e-commerce, e-farming and e-financial wallet.

According to ${ }^{[10]}$ Information technology provides a more diverse and extensive scope of information on politics and the political system of a country. He further say that It helps people to be better informed and educated about political affairs such that they develop the capacity to critically evaluate how democratic institutions operate in their country. In the same vein ${ }^{[20]}$ also agree that Technological and communication breakthroughs have restructured the way governments and non-governmental organisation to interact with their citizens, especially given the population configuration which is mostly youth based. He further believe that Various stakeholders distressed with the challenges of manual methods of conducting elections in Nigeria, have begun a call for Election management bodies and government to explore the possibility of adopting e-voting system in the country. Although with the 2015 general election in Nigeria show a green light that Nigeria will embrace electronic voting in the near feature.

Abuja is one of the best city among Nigerian states in terms of infrastructure and technology. Information and Communication Technology (ICT) is today a crucial growth enabler with enormous impact in Abuja because everything is online. The nature of governance, business, education and social engagements is speedily and dramatically changing in the state. Almost all governmental and private organizations has a web site for dissemination and receiving of information these include Nigerian Communication Commission (NCC), Central Bank of Nigeria, all commercial Banks, National Information Technology development Agency (NITDA), all Nigerian Army Forces, Nigerian Police Force, Nigerian Immigration Service, Nigerian Custom Service, Nigerian Prison service, Nigerian Road safety Commission, Federal Inland Revenue, all Ministries, all academic institutions, Pension Com- missions, Nigerian Bar Association, National Assembly, Nigerian National Petroleum Corporation (NNPC) and all other oil and gas companies, all aviation companies, Independent National Electoral Commission (INEC), all Mobile companies, presidency and Federal Capital Territory Abuja etc. with the emergence of smartphones in Abuja all of this are easy to locate by every citizen in the state.

Similarly, ${ }^{[3]}$ indicate that most of the Nigerian institutions have a web site however majority of them are not up to date. They further indicate that e-government application in Nigeria includes Police dairy, public radio phone in program where citizens can interact with police laying complaints or reporting on right abuse. Others includes, e-passport, Voters registration, tax payment, land registration and e payment. There is a compelling necessity to integrate our entire website in Abuja in order to attain a full fledge e-government like Seoul in Korea. The Seoul Metropolitan Government is leading the world in smart administration it pursue drastic improvements in administrative efficiency and quality through the in cooperation of advanced information and communication technologies into its public services for citizens. Seoul discloses all of its administrative information to citizens and shares public data with them. Offering job opportunities for them, provide useful information such as real estate transactions and rental, cultural events etc. with the emerge of mobile devices Seoul uses e-voting system enable her citizens to participate in policy making process.

The aim of this research is to assess the effectiveness of E-government in Federal capital territory of Nigeria Abuja with concentration on the Behavioral, Technical, Law and policy levels. With the following objectives:

(1) To assess the effective use of IT appliances among citizens of Abuja

(2) To identify the major challenges hindering e-government in Abuja

(3) To recommend on how to achieved full fledge e-government in Abuja

\section{Research Questions}

(1) What is the effectiveness of E- government in Abuja?

(2) What are the challenges hindering the full implementation of e-government in Abuja?

\section{Conceptual Framework}

The effectiveness of e-government relied on the effective use of information and communication technology (ICT) in leadership, policies, economic, democracy, education, community, health, Security, legal framework so as to 
achieved transparency, trust in e-services, efficiency, accountability and accessibility etc. although, Edward and Charles ${ }^{[3]}$ identified seven (7) challenges hindering e-government implementation in Nigeria are; Low ICT literacy rate, Lack of necessary regulatory/legal framework, Poor ICT infrastructure, Corruption, Lack of Committed Leadership, Epileptic Power supply and Bureaucratic Bottlenecks. For Nigeria to realized there dream in e-government and e-governance Kabir, ${ }^{[7]}$ recommended that; (1) Encourage more private sector involvement in ICT capacity development and ICT provision in the country. (2) Involve information professionals in formulation of information policies. (3) Expedite actions on passing the data protection bill into law. (4) Collaborate with other countries within and outside the African continent to formulate information policy that can guide regional and international exchanges and transactions.

"Addressing the needs of the neediest especially the vulnerable groups such insurgencies, migrants and other humanitarian crisis that is affecting the rural people technologies offer a platform for them to be had ${ }^{[17],}$,

\section{Method}

This research must have a plan and strategy of investigation; it must have a format and a modus operandi, so as to obtain answer to research question and to control variables. This plan strategy of investigation is the research design. The research design is a program that guides the investigation in the process of collecting, analyzing and interpreting observations. In this study of survey research, both the questionnaire and interview approach was adopted. Here, the representation of the population was studied and the results were generalized. This is because of inability to visit the entire governmental and non-governmental organization in Abuja. Information for this research was gathered by issuing questionnaire to employees in the various sectors.

\subsection{Research Population}

In a bid to carry out a thorough, meaningful and all-embracing research study, the population for this research comprised civil servant which include IT professional non IT personnel security personnel, Bankers, business men and customers and citizens etc. from the sector which were chosen randomly. The random selection of the population is as a result of the need to have a cross section of opinions within the area of study and the little time and resources at the disposal of the researcher. However, it is believed and hoped that the population chosen would represent a true picture of what is on ground.

\subsection{Sampling Techniques}

The sample size of this research covers only some sectors in Abuja. Out of the whole states in Nigeria, Abuja was chosen by the researcher because of the fact that Abuja is close to the researcher whore enough information could be obtained for the purpose of the study. Also the selection of Abuja as a sample size saves the researcher the cost of touring round the entire states in the country. This has made the researcher to employ convenient sampling in the selection of Abuja. The sampling technique employed here is the random sampling. This is so as to have an effective result, from just a sample population of 120. This comprises both the citizens and the civil servants in the Federal Capital Territory of Nigeria Abuja.

\subsection{Instrument Design}

Questionnaire is the main instrument used in the collection of relevant data for this research, and it is designed in a way that although being very concise, would aid the collection of relevant material that would aid the research work. Please refer to appendix X for the instrument as designed and presented to would be respondents.

\section{Results and Discussion}

Simple percentage has been used to analyze the results throughout this research.

Table 1. Age of the Respondent

\begin{tabular}{|c|c|c|}
\hline ITEMS (YEARS) & RESPONDENTS & PERCENTAGE (\%) \\
\hline $18-29$ & 27 & 43.54 \\
\hline $30-39$ & 21 & 33.87 \\
\hline $40-49$ & 8 & 12.91 \\
\hline $50-59$ & 4 & 6.45 \\
\hline 60 and above & 2 & 3.23 \\
\hline TOTAL & 62 & 100 \\
\hline
\end{tabular}

Source: Field survey, 2019.

\section{AGE OF THE RESPONDENTS}

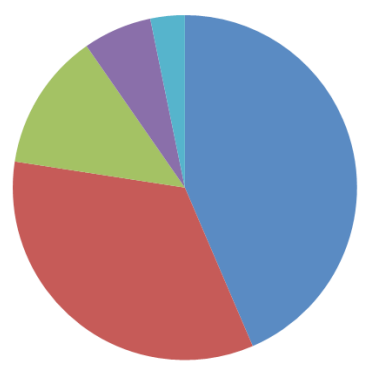

$18-29$

- 30-39

40-49

- 50-59

60 and above

Figure 1. Age of the respondents 
The highest percentage of responses between the age of $18-29$ years and it is 27 people which is $43.54 \%, 30-$ 39 years is 21 people which is $33.87 \%, 40-49$ years is also 8 people which is $12.91 \%, 50-59$ years is 4 respondents which is $6.45 \%$ while 60 and above years had 2 people representing $3.23 \%$. as shown in the pie chart below:

Table 2. Occupation of the Respondent

\begin{tabular}{|c|c|c|}
\hline ITEMS (OCCUPATION) & RESPONDENTS & PERCENTAGE (\%) \\
\hline Bankers & 3 & 4.84 \\
\hline Civil servant & 31 & 50 \\
\hline Military/Paramilitary & 4 & 6.45 \\
\hline Others & 24 & 38.71 \\
\hline TOTAL & 62 & 100 \\
\hline
\end{tabular}

Source: Field survey, 2019.

The highest percentage of responses where civil servants and it is 31 people which is $50 \%$, Bankers is 3 people which is representing $4.84 \%$, Military/Paramilitary is 4 people which is representing $6.45 \%$ while others is 24 respondents which is representing $38.71 \%$ as shown in the figure below:

\section{OCCUPATION OF THE RESPONDENTS}

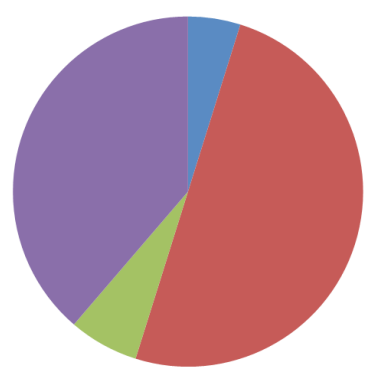

Bankers

n Civil servant

Military/Paramilitary

- Others

\section{Discussion of the Findings}

From the Table 3 above show the outcome from the respondent. It is clearly shown that electronic governance initiatives has decrease civil servants corruption in Abuja which about $41.9 \%$ of the respondent agree upon at this point now there is a compelling necessity to increase at least $80 \%$ so that Nigeria will maintain the level stated in ${ }^{[1]}$ that Nigeria is a giant of Africa. $46.8 \%$ of the respondent

Table 3. The effectiveness of e-government in Abuja

\begin{tabular}{|c|c|c|c|c|c|c|c|c|c|c|c|}
\hline $\mathbf{S} / \mathbf{N}$ & Item & SA & $\%$ & $\mathbf{A}$ & $\%$ & $\mathbf{N}$ & $\%$ & DA & $\%$ & SD & $\%$ \\
\hline 1. & e-government initiatives have decreased civil servants corruption in Abuja & 21 & 33.87 & 26 & 41.94 & 8 & 12.91 & 5 & 8.06 & 2 & 3.2 \\
\hline 2. & E-government services has increased citizens trust in Abuja & 14 & 22.6 & 29 & 46.81 & 10 & 16.1 & 8 & 12.91 & 1 & 1.61 \\
\hline 3. & $\begin{array}{l}\text { Government and private sector has reduced administrative cost due e-govern- } \\
\text { ment services in Abuja }\end{array}$ & 10 & 16.1 & 27 & 43.55 & 20 & 32.31 & 2 & 3.21 & 3 & 4.81 \\
\hline 4. & $\begin{array}{l}\text { E-government has bridge the gap between citizens and the governance in Abu- } \\
\text { ja }\end{array}$ & 14 & 22.61 & 22 & 35.51 & 17 & 27.41 & 8 & 12.91 & 1 & 1.61 \\
\hline 5. & E-government initiative have increased the efficiency of system in general & 17 & 27.41 & 19 & 30.61 & 15 & 24.21 & 8 & 12.91 & 3 & 4.81 \\
\hline 6. & $\begin{array}{l}\text { E-government initiative have increased the accessibility to the government in } \\
\text { Abuja }\end{array}$ & 13 & 20.96 & 27 & 43.51 & 2 & 3.21 & 10 & 16.11 & 10 & 16.11 \\
\hline 8. & E-government has improved security in Abuja & 7 & 11.31 & 23 & 37.11 & 14 & 22.61 & 11 & 17.71 & 7 & 11.31 \\
\hline 9. & $\begin{array}{l}\text { Health sectors, academics, businesses, transportation and judiciary utilize } \\
\text { e-government services effectively in Abuja }\end{array}$ & 9 & 14.51 & 20 & 32.31 & 13 & 20.96 & 12 & 19.35 & 8 & 12.91 \\
\hline 10. & E-government has increased the quality of decision making in Abuja & 6 & 9.71 & 14 & 22.58 & 22 & 35.51 & 12 & 19.35 & 8 & 12.91 \\
\hline 11. & $\begin{array}{l}\text { Lack of IT infrastructure is the major problem affecting E-government in Abu- } \\
\text { ja }\end{array}$ & 31 & 50 & 23 & 37.11 & 3 & 4.81 & 3 & 4.81 & 2 & 3.21 \\
\hline 12 & Corruption is the major factor affecting E-government in Abuja & 31 & 50 & 20 & 32.31 & 4 & 6.45 & 5 & 8.06 & 2 & 3.21 \\
\hline 13. & $\begin{array}{l}\text { Lack of technical know-how in ICT is major factor affecting E-government in } \\
\text { Abuja }\end{array}$ & 28 & 48.21 & 22 & 35.51 & 3 & 4.81 & 7 & 11.31 & 2 & 3.21 \\
\hline 14. & Bureaucratic system is the major factor affecting e-government in Abuja & 20 & 32.21 & 27 & 43.51 & 10 & 16.11 & 3 & 4.81 & 2 & 3.21 \\
\hline
\end{tabular}

Source: Field survey, 2019. 
agreed that electronic government has increased citizens trust particularly in Abuja which shows positive impact. In both the private and government sector electronic government decrease running cost of the organization where $43.5 \%$ of the respondent agreed upon. Also $35.5 \%$ of the respondents agreed that electronic governance bridge the gap between the citizens and the government in Abuja there is a need to increase to at least $80 \%$ so as to maintain the level as compare with ${ }^{[20]}$. The respondent from the table 3 above $30 \%$ of the respondents agreed electronic governance initiatives help in increasing the efficiency in system of governance in general, it also increase the accessibility to the government where about $43.5 \%$ of the respondent agreed. It is given from the table 3 above about $58.1 \%$ of the respondent agreed that NITDA is also contributing a lot in promoting e-government in Abuja. $37.1 \%$ of the respondents agreed that e-government has improved the security in Abuja there is a need to increase so as to confirmed what ${ }^{[2]}$ and ${ }^{[9]}$ ascertained. The outcome from the respondents in Table 3 above shows that health, transportation, businesses, judiciary, and academic institutions are benefiting from the current state of e-governance in Abuja in which $32.3 \%$ of the respondents agreed upon however, the percentage here is less to confirmed with the assertion of ${ }^{[9]}$. Moreover, $35.5 \%$ of the respondents are neutral in terms of the effectiveness of e-governance in relation to decision making that is either e-governance increase the quality of decision making in Abuja or not. About $50 \%$ of the respondents strongly agreed that lack of information technology infrastructure is the major problems affecting e-government in Abuja. Also 50\% of the respondents strongly agreed that corruption is one of the major factors that affect e-government in Abuja. It was also shown that lack of technical know-how in ICT is major factor affecting electronic government in Abuja in which $45 \%$ of the respondents strongly agreed upon. Finally, $43.5 \%$ of the respondents agreed that bureaucratic system of government is also a bottle neck to e-government in Abuja.

\section{Conclusions}

E-government has the potential to greatly improve how government operates internally and how it serves its customers. E-government is much more than a tool for improving cost-quality ratios in public services. It is an instrument of reform and a tool to transform government. Thus, e-Government is not primarily about automation of existing procedures but about provide new ways of doing businesses and service delivery using recent technologies. Based on this research work e-government have decreased civil servant corruption in Abuja, government organiza- tion and private sector have reduced administrative cost in Abuja, and e-government initiative have increased the efficiency of the system of administration and the study shows that e-governance has increased security in Abuja. From this perspective, the success of e-government is the result of organizing human, material and technical resources through the backing by the strong determination and leadership of the president, which were efficiently utilized to achieve the objective of administrative efficiency, improve service to mass public, improve administrative process transparency, and citizens participation and applied the advancing information technologies. Simultaneously, information industry promotion with the objective of advancing the IT industry was also implemented in each stage of the project as well as applying feedback and research results of previous experience on the next phase planning. Moreover, the findings shows that lack of IT infrastructure is one of the problems affecting e-government in Abuja it also reveal that corruption is affecting the e-government in Abuja.

\section{Recommendation}

The key strategy to make e-governance effective is formation of right institution and agencies and identifying the right human resources for the same. Based on the findings of this work the following recommendation has been made;

(1) Full implementation of E-government in Nigeria will reduce high level of corruption

(2) To create a central payment system of the entire country staff to avoid Goss workers.

(3) To develop smart city for the entire state of Abuja there by making decision by the citizen of the state.

(4) To have one central free internet service for all the state to enable people have access to information at all the time

\section{References}

[1] Adah, B. A. The Status and Nature of E-governance in Nigeria, University of Uyo, 2015.

[2] Andrew L., Robert D. A. Breaking Down Bureaucratic Barriers: the next phase of digital government. Progressive Policy Institute, 2001.

[3] Edward O., Charles O. New Wine in old Wine Skin: An Exploration of Major Constraints to e-Government Implementation in Nigeria. European Scientific Journal, 2014, 10 (14): 481-487.

[4] Fatile J. O. Electronic Governance: Myth or Opportunity for Nigerian Public Administration? International Journal of Academic Research in Business and 
Social Sciences, 2012, 2(9) [online] available online at:

www.hrmars.com/journals [accessed 8th January, 2016].

[5] Janet C. The Quest for Economic Government: A defining Version. Institute for Electronic Government, IBM cooperation, 1999.

[6] John D. E-Governance: A Weapon for the Fight against Corruption in Nigeria [online] Published by saharareport. 2013. Comavailable online from: http://saharareporters.com/2013/08/10/e-governance-weapon-fight-against-corruption-nigeria-john-danfulani-phd

[7] Kabir M. Global Best Practices in Digital Electoral Process: The Effects and Benefits of e-Electoral Process for a Developing Country (Nigeria), E-Nigeria conference 2015, Abuja 17th to 19th November 2015.

[8] Rand A. O., Emad A. A. Drivers of E-Government and E-Business in Jordan. Journal of Emerging Technologies in Web Intelligence, 2010, 2(3): 204 -211.

[9] Sharon S. D. The Evolution and Continuing Challenges of E-governance. Public Administration Review, 2008, 68(Special issues).

[10] Samuel Z. Cyber Warfare and its Relationship to Electoral Processes. E-Nigeria conference 2015, Abuja 17th to 19th November 2015.

[11] Valentina D. N. E - Government for Developing Countries: opportunities and Challenges The Electronic Journal on Information Systems in Developing Countries, 2004, 18(1): 1-24.

[12] Saidu, A. E-governance Delivery through Informa- tion and Communication Technology (ICT), 2016.

[13] Saxena, K. B. C. Towards excellence in e-governance. International Journal of Public Sector Management, 2005.

[14] Heeks, R. Understanding e-governance for development, 2001.

[15] Dawes, S. S. The evolution and continuing challenges of e-governance. Public Administration Review, 2008, 68: S86-S102.

[16] Palvia, S. C. J., Sharma, S. S. E-government and e-governance: definitions/domain framework and status around the world. In International Conference on E-governance, 2007, 5: 1-12).

[17] United Nation E-governance survey. Gearing E-Government To Support Transformation Towards Sustainable And Resilient Societies. 2018.

[18] United Nation. Transforming our World: the 2030 Agenda for Sustainable Development. 2015. [online] Available at:

https://sustainabledevelopment.un.org/content/documents $/ 21252030 \% 20$ Agenda $\% 20$ for $\% 20$ Sustainable\%20Development\%20web.Pdf

[19] UNDESA. World Public Sector Report "Working Together: Integration, Institutions and The Sustainable Development Goals", 2018, 5. Available at: https://publicadministration.un.org/en/Research/ World-Public-Sector-Reports

[20] UNDESA. Guide on Lessons for Open Government Data Action Planning for Sustainable Development, 2017. Available at: http://workspace.unpan.org/sites/Internet/Documents/UNPAN97913.pdf 